\title{
A Dental Metric Study of Medieval, Post Medieval, and Modern Basque Populations from Northern Spain
}

\author{
Diana Malarchik ${ }^{1 *}$, Marin A. Pilloud ${ }^{2}$, and G. Richard Scott ${ }^{2}$ \\ ${ }^{1}$ University of California, Davis \\ 2 University of Nevada, Reno
}

Keywords: odontometrics, Basques, dental variation, biodistance

\begin{abstract}
Basque population history has been examined through classic genetic markers, mtDNA, Y chromosome haplogroups, craniometrics, and recently dental morphology. Dental morphological data show Basques have a classic European dental pattern but fall as an outlier among European populations. Expanding on that work, Basque tooth size was examined to further evaluate the affinities of the Basque population. Mesiodistal and buccolingual maximum crown measurements were taken from medieval and post medieval skeletons from the Catedral de Santa María in Vitoria, Spain, along with living samples of modern Basques, Spanish, and Spanish Basques from dental students at the Universidad del País Vasco. A dental metric examination affirms the outlier status of Basques, as they exhibit smaller crown areas than neighboring populations. In biodistance analyses Basque populations group with linguistically and geographically distant populations. Even with gene flow from Spain, France, and North Africa, Basque individuals still demonstrate a unique pattern coincident with their ancient origins.
\end{abstract}

The Basque Country, Euskalherria, is located in the southwestern corner of France and north central Spain. The population of the region is well known for its unique language, as "the sole surviving preIndo European language of Western Europe" (Trask, 1997:35). Many anthropological approaches have been taken to better understand the place of Basques in European history, from linguistic to archaeological research, and more recently investigating genetic haplotypes. Early research explored Basque blood groups, finding that Basques had high frequencies of the blood type $\mathrm{O}$ allele (ca. 75\%), low rates of blood type B allele (ca. $3 \%$ ), and the world's highest frequencies of the negative allele (" $r$ " or "cde") in the Rhesus blood group system (ca. 50\%) (Roychoudhury and Nei, 1988). These frequencies set them apart from other Western Europeans (Alberdi et al., 1957; Chalmers et al., 1948; van der Heide et al., 1952). These unusual blood types were interpreted by CavalliSforza (2000) as a possible link to the first wave of people coming into Europe during the Paleolithic and served as the stimulus for many genetic studies to examine the origins and affinities of the Basque population. Analyses of mitochondrial DNA (mtDNA) show unique haplogroups suggesting in situ evolution with minimal gene flow (Alzualde et al., 2005; Alzualde et al., 2006; Martinez-Cruz et al., 2012). Y chromosome polymor- phisms show low levels of diversity, suggesting that this population has been evolving in the region for millennia (Alonso et al., 2005; Hurles et al., 1999).

More recently, data on Basque dental morphology was investigated to explore the population history of this group. Typically, European populations are classified by morphologically simple teeth where trait absence is more common than trait presence (Scott and Turner, 1997). Scott and colleagues (2013) found that Basque samples, both historic and living, have high rates of hypocone and hypoconulid reduction on UM2 and LM2, respectively. There is also an extremely high frequency of double rooted lower canines, a classic European trait (Scott et al., 2013; Scott and Turner, 1997). These findings place Basque groups into the overall category of Western Europe, within the 'Eurodont' dental pattern (as coined by that study). There is no single trait that separates the Basques
*Correspondence to:
Diana Malarchik
Department of Anthropology
University of California, Davis
dmalarchik@ucdavis.edu 
from other European groups. It is rather the accumulation of slight but consistent differences that create their outlier status (Scott et al., 2013).

To further explore dental variation among Basque populations we evaluate here dental metrics. The goal of the present study is to determine if the unique population history of the Basques is evident in tooth crown size throughout time. If preceding studies are any indicator, it is expected that Basques will show tooth size patterns like those of the other Western Eurasian groups, with slight differences reflecting their long-term occupancy in Western Europe along with relative geographic isolation. It is further expected that these patterns will be evident from Medieval to modern times.

\section{Materials and Methods}

The skeletal remains examined in this study were collected from the Catedral de Santa María in Vitoria-Gazteiz, Alava, País Vasco, Spain. These remains date from the $11^{\text {th }}$ to the $19^{\text {th }}$ century, and were also the subject of studies on dental morphology (Scott et al., 2013), oral health (Hopkinson, 2009), craniometry (Janzen, 2011), dental chipping (Scott and Winn, 2010), and taphonomy (Hopkinson et al., 2009). Sex was estimated by one of the authors (GRS) based on skull and pelvic morphology (Buikstra and Ubelaker, 1994).

Additionally, dental casts were collected from living people by Alberto Anta at the University of the Basque Country from students who were enrolled in the dental school at that time. For these individuals, sex and cultural identification

(Basque, Spanish-Basque, or Spanish) were recorded at time of casting.

Maximum crown measurements were taken by one of the authors (GRS) following Moorrees (1957). Measurements were taken on the left side of the dental arcade. The right antimere was substituted in cases of antemortem or postmortem tooth loss, gross carious lesions, excessive wear, or any other condition that would make the left side unobservable. Teeth with large carious lesions, excessive dental calculus, or marked occlusal wear were omitted from analysis. Table 1 is a summary of material available for study in this analysis.

Along with maximum mesiodistal (MD) and buccolingual (BL) crown measurements, two additional measurements were calculated. Tooth size as the product of the maximum crown dimensions was also analyzed (TS=MDxBL) as was total crown area for each tooth type. Crown area was defined as the sum of TS ( $\Sigma T S$ ) for all teeth in a single tooth class, with the exception of the third molar.

To analyze sexual dimorphism, the male mean was divided by the female mean of each measurement for each tooth, and then multiplied by 100 (Garn et al., 1967b; Harris, 1997). Sexual dimorphism was also examined through a multivariate analysis of variance (MANOVA) and a Student's ttest. Statistical significance was measured using the Bonferroni correction. Principal components analysis (PCA) and discriminant function analysis (DFA) were used to explore differences between populations.

Three major benefits of using a PCA in the study of human tooth size variation include: (1) reducing data on inter-correlated variables into compound variables; (2) extracting the major developmental fields controlling tooth size; and (3) providing statistically independent measures for between group comparisons (Harris, 1997). The extracted components were then used in Euclidean

Table 1. Male and female samples by time period.

\begin{tabular}{|c|c|c|c|c|}
\hline Time Period & Population & Location of Collection & Male (n) & Female (n) \\
\hline $\begin{array}{l}\text { Medieval } \\
(1100-1350)\end{array}$ & Basque & $\begin{array}{c}\text { Catedral de Santa Ma- } \\
\text { ria }\end{array}$ & 65 & 28 \\
\hline $\begin{array}{l}\text { Post Medieval } \\
(1400-1850)\end{array}$ & Basque & $\begin{array}{c}\text { Catedral de Santa Ma- } \\
\text { ria }\end{array}$ & 90 & 126 \\
\hline $\begin{array}{l}\text { Modern } \\
(2005)\end{array}$ & $\begin{array}{l}\text { Spanish } \\
\text { Spanish-Basque } \\
\text { Basque }\end{array}$ & $\begin{array}{c}\text { Dental Casts; Universi- } \\
\text { dad del País Vasco, } \\
\text { Dental School }\end{array}$ & $\begin{array}{c}8 \\
13 \\
8\end{array}$ & $\begin{array}{l}48 \\
39 \\
28\end{array}$ \\
\hline Total & & & 184 & 269 \\
\hline
\end{tabular}


distance analysis in which Ward's dendrograms were created.

Tooth apportionment was used to create residual scores, where the expected variation (PCA on the sum of the dental arcades) was subtracted from the observed variation (PCA for all individual tooth measurements). These are used to view a group's variation in the entire dentition or by morphogenetic fields, depending on research questions and available data sets (Harris, 1997).

The use of residual scores shows each group's variation from their predicted overall tooth size. These residual scores can be visualized through bar graphs or the scores can be subjected to further statistical analysis to show population grouping. The axis on which the scores are plotted represents the expected size of the dentition for each sample; negative scores, as indicated by bars plotting below the expected line, show teeth that are smaller than expected, while positive scores show teeth that are larger than expected. Analysis using residual scores allows published mean scores to be used, expanding sample sizes in comparative analyses (Harris and Rathbun, 1991).

While PCA emphasizes variation within populations, discriminant function analysis examines variation by maximizing differences between groups and minimizing variation in a group (Kachigan, 1986). Raw data are required to run a discriminant function; therefore, this method was only used to examine variation for samples collected as part of this study. Using these samples, a stepwise DFA was used to compare Basque temporal periods. All analyses were conducted in SPSS version 22 (IBM Corp., 2013).

To explore population variation, eighty-two comparative samples of summary statistics of dental metrics were assembled from published sources (Table 2). These samples cover multiple temporal periods and geographic areas and were divided into five regions (Western Eurasia, Sino America, Sahul Pacific, Sunda Pacific, and Sub Saharan Africa) for comparisons described by Scott and Turner (1997). To examine Basque variation, analyses focused on: (1) temporal variation within the Basque samples; (2) Basque variation viewed on a continental level comparing Basque samples to Western Eurasian groups; and (3) Basque variation in a global context.

\section{Results}

Dental metrics were evaluated for sexual dimorphism within the five samples: medieval, post medieval, modern Basque, Spanish, and Spanish
Basque. The degree of sexual dimorphism ((male mean/ female mean)*100) is in line with other odontometric studies (Moorrees 1957; Keiser 1990) that show males with teeth on average 2-4\% larger than females, with canines slightly more dimorphic at $4-6 \%$ (Table 3). The modern Basque sample was the only sample to vary, with males not exhibiting larger teeth than the females, although this is most likely due to the over representation of females in the sample (see Table 1).

First, temporal variation was examined. A cross -validated stepwise DFA classified individuals into one of three groups (medieval, post medieval, or modern) with an accuracy of $46.4 \%$, which is slightly better than random chance (Table 4). Medieval and modern samples have the highest percentages of correct classification, both around 70\%, while the post medieval was the hardest to classify with a rate of $27 \%$. Poor classification of the post medieval group was expected, as this transitional group most likely represents the median between the medieval and modern groups, thus allowing for incorrect classifications to occur more frequently.

Crown areas were used to examine differences between temporal periods and population. Plotting anterior and posterior crown areas for all populations collected, there is a clear shift in tooth size as time increases. Although among males, there is a shift from the expected, as the modern Basque populations have slightly smaller teeth than medieval Basques (Figure 1). This is mostly likely due to the poor representation of males in the modern sample, where males were underrepresented in the dental school population when the casts were collected. When looking at females, post medieval Basques show larger tooth size for both premolars and molars when compared to medieval Basque samples (Figure 2). Premolars show an increase in size of $5.7 \%$ while molars increased by $6.6 \%$. Modern Basques exhibit larger teeth than the post medieval samples at $8.3 \%$ in premolars and $1 \%$ in molars.

Examining Basque tooth crown apportionment along with other Western Eurasian populations from the published literature, residual factors for all dental arcades were used to make bar graphs following the methods of Harris and Rathbun (1991). As tooth crown measurements are sexually dimorphic, males and females were analyzed separately. Examining all measurements for male European samples, medieval Basques show scores of disproportionally small teeth, with post medieval Basques and medieval Norwegians falling interme- 
Table 2. Published comparative samples used in analyses by region.

\begin{tabular}{|c|c|c|}
\hline Region & Population & Citation \\
\hline \multirow[t]{22}{*}{ Western Eurasia } & Anglo-Saxon & Lavelle 1968 \\
\hline & Bedouin & Rosenzweig and Zilberman 1969 \\
\hline & British & Lavelle 1968 \\
\hline & Caucasus & Kieser et al. 1985 \\
\hline & Circassian (Israel) & Koyoumdjisky-Kaye et al. 1977 \\
\hline & Coimbra & Galera and Cunha 1993 \\
\hline & Druse & Koyoumdjisky-Kaye et al. 1977 \\
\hline & English & Lavelle 1968 \\
\hline & Finland & Alvesalo 1985 \\
\hline & Iceland & Axelsson and Kirveskari 1983 \\
\hline & Jewish Cochini & Rosenzweig and Zilberman 1967 \\
\hline & Medieval Norwegians & Beyer-Olsen and Alexandersen 1995 \\
\hline & Modern Greek & Zorba et al. 2011 \\
\hline & Modern White & Axelsson and Kirveskari 1983 \\
\hline & North Finland & Kirveskari et al. 1977 \\
\hline & NP Lapp & Kirveskari 1977 \\
\hline & Pashtun & Sakai et al. 1971 \\
\hline & Rural Ancient Greek & Henneberg 1998 \\
\hline & Skolt Lapps & Kirveskari 1977 \\
\hline & South African Whites & Kieser et al. 1985e \\
\hline & Tristan da Cunha & Thomsen 1955 \\
\hline & Urban Ancient Greek & Henneberg 1998 \\
\hline \multirow[t]{29}{*}{ Sino America } & Adena & Sciulli 1979 \\
\hline & Ainu & Brace and Nagai 1982 \\
\hline & Aleut & Moorrees 1957 \\
\hline & Cahokia Mound 72 & Thompson 2013 \\
\hline & Canadian Eskimo (Iglooik) & Mayhall 1979 \\
\hline & Canadian Eskimo $(\mathrm{HB})$ & Mayhall 1979 \\
\hline & Chinese Bronze & Brace 1976 \\
\hline & East Greenland Eskimo & Pedersen 1949 \\
\hline & Glacial Kane & Sciulli 1979 \\
\hline & Fukuoka & Brace and Nagai 1982 \\
\hline & Highland Beach & Iscan 1989 \\
\hline & Hopewell & Sciulli 1979 \\
\hline & Indian Knoll & Perzigian 1976 \\
\hline & Jomon & Brace and Nagai 1982 \\
\hline & Kansas Schultz Mound & Phenice 1969 \\
\hline & Korean & Brace and Nagai 1976 \\
\hline & Kyoto & Brace and Nagai 1982 \\
\hline & Lengua & Kieser et al. 1985e \\
\hline & Pecos & Nelson 1938 \\
\hline & Shanghai & Brace and Nagai 1982 \\
\hline & St. Lawrence Island Eskimo & Scott and Gillispie 2002 \\
\hline & Tennessee (A) & Hinton et al. 1980 \\
\hline & Tennessee (M) & Hinton et al. 1980 \\
\hline & Tennessee $(\mathrm{W})$ & Hinton et al. 1980 \\
\hline & Tibet & Sharma 1983 \\
\hline & Ticuna & Harris and Nweeia 1980b \\
\hline & Xi Shang Neolithic & Brace, Shao, Zhang 1984 \\
\hline & Yayoi & Brace and Nagai 1982 \\
\hline & Yunnan & Brace and Nagai 1982 \\
\hline
\end{tabular}


Table 2. Published comparative samples used in analyses by region (cont'd).

\begin{tabular}{|c|c|c|}
\hline Region & $\begin{array}{r}\text { Population } \\
\end{array}$ & $\begin{array}{r}\text { Citation } \\
\end{array}$ \\
\hline \multirow[t]{5}{*}{ Sahul Pacific } & Australian Aborigine & Campbell 1925 \\
\hline & Broadbeach & Smith et al. 1981 \\
\hline & Bougainville (Solomon Islands) & Bailit et al. 1968 \\
\hline & Walbiri, Australia & Barrett et al. 1963,64; Brace 1980 \\
\hline & Western Australia & Freedman and Lofgren 1981 \\
\hline \multirow[t]{16}{*}{ Sunda Pacific } & Cook Island, Mangaia & Yamada et al. 1988 \\
\hline & Cook Island, NS Group & Yamada et al. 1988 \\
\hline & Cook Island, Pukapuka & Yamada et al. 1988 \\
\hline & Cook Island, Rarotonga & Yamada et al. 1988 \\
\hline & Cook Island, S Group & Yamada et al. 1988 \\
\hline & Javanese Bronze & Brace 1976 \\
\hline & Java & Brace 1980 \\
\hline & India (Chalcolithic) & Lukacs 1985 \\
\hline & India & Acharya and Prabhu 2011 \\
\hline & India & Walimbe 1985 \\
\hline & Philippines & Potter et al. 1981 \\
\hline & South-east Java & Taverne 1980 \\
\hline & Tajik & Sakai et al. 1971 \\
\hline & Thai & Brace 1976 \\
\hline & Thai Bronze & Brace 1976 \\
\hline & Yang Shao Neolithic & Brace, Shao, Zhang 1984 \\
\hline \multirow[t]{9}{*}{ Sub Saharan Africa } & Bantu & Shaw 1931 \\
\hline & Griqua & Kieser 1985 \\
\hline & San & van Reenan 1982 \\
\hline & San & Drennan 1929 \\
\hline & South African Black, Contemp. & Kieser et al. 1987 \\
\hline & South African Black & Kieser et al. 1987 \\
\hline & South African & Jacobsen 1982 \\
\hline & Southern African & van Reenan 1982 \\
\hline & Teso & Barnes 1969 \\
\hline
\end{tabular}

Table 3. Sexual dimorphism separated by temporal period

\begin{tabular}{lccccccc}
\hline & UI1MD & UI2MD & UCMD & UP1MD & UP2MD & UM1MD & UM2MD \\
Medieval & 105.23 & 105.39 & 104.00 & 103.66 & 103.64 & 103.86 & 106.09 \\
Post Medieval & 100.65 & 103.54 & 103.26 & 101.29 & 102.57 & 101.44 & 102.32 \\
Spanish & 102.79 & 104.51 & 102.39 & 101.71 & 103.35 & 102.29 & 101.26 \\
Spanish-Basque & 103.54 & 103.95 & 104.94 & 106.74 & 102.89 & 105.45 & 105.95 \\
Basque & 105.32 & 102.95 & 102.46 & 99.49 & 95.94 & 95.78 & 97.56 \\
& UI1BL & UI2BL & UCBL & UP1BL & UP2BL & UM1BL & UM2BL \\
Medieval & 103.21 & 104.73 & 102.54 & 102.61 & 103.97 & 103.30 & 105.78 \\
Post Medieval & 104.60 & 106.96 & 103.82 & 101.24 & 101.43 & 102.57 & 102.97 \\
Spanish & 105.88 & 103.77 & 103.04 & 100.68 & 102.82 & 101.73 & 104.15 \\
Spanish-Basque & 111.28 & 115.41 & 112.71 & 106.27 & 107.18 & 104.27 & 108.62 \\
Basque & 100.43 & 106.32 & 104.92 & 99.18 & 97.60 & 100.10 & 101.38 \\
& LI1MD & LI2MD & LCMD & LP1MD & LP2MD & LM1MD & LM2MD \\
Medieval & 97.15 & 101.33 & 102.02 & 103.46 & 104.94 & 105.25 & 104.84 \\
Post Medieval & 100.87 & 102.08 & 102.70 & 102.13 & 100.64 & 104.55 & 103.82 \\
Spanish & 102.99 & 104.47 & 102.55 & 100.60 & 100.55 & 100.16 & 102.38 \\
Spanish-Basque & 101.01 & 103.32 & 106.08 & 105.62 & 104.61 & 104.09 & 105.44 \\
Basque & 98.75 & 102.67 & 99.94 & 101.68 & 85.40 & 98.63 & 96.10 \\
& LIBL & LI2BL & LCBL & LP1BL & LP2BL & LM1BL & LM2BL \\
Medieval & 101.56 & 101.57 & 103.89 & 102.50 & 102.69 & 101.87 & 102.42 \\
Post Medieval & 103.11 & 102.47 & 107.93 & 102.21 & 101.35 & 103.37 & 104.23 \\
Spanish & 104.25 & 98.66 & 102.38 & 100.49 & 99.43 & 102.80 & 103.35 \\
Spanish-Basque & 110.68 & 103.49 & 107.82 & 110.29 & 106.93 & 106.86 & 108.19 \\
Basque & 103.33 & 99.63 & 97.08 & 98.06 & 99.64 & 97.40 & 97.58 \\
\hline
\end{tabular}


Table 4. Cross-Validated, Stepwise DFA Summary for all Basque temporal periods.

\begin{tabular}{lccccc}
\hline & Assigned Group & \multicolumn{4}{c}{ Predicted Group Membership } \\
\hline \multirow{3}{*}{ Count } & & Medieval & Post Medieval & Modern & Total \\
& Medieval & 42 & 14 & 5 & 61 \\
& Post Medieval & 69 & 31 & 15 & 115 \\
& Modern & 3 & 7 & 25 & 35 \\
\hline Percentage & Medieval & $68.9 \%$ & $23.0 \%$ & $8.2 \%$ & $100.0 \%$ \\
& Post Medieval & $60.0 \%$ & $27.0 \%$ & $13.0 \%$ & $100.0 \%$ \\
& Modern & $8.6 \%$ & $20.0 \%$ & $71.4 \%$ & $100.0 \%$ \\
\hline
\end{tabular}

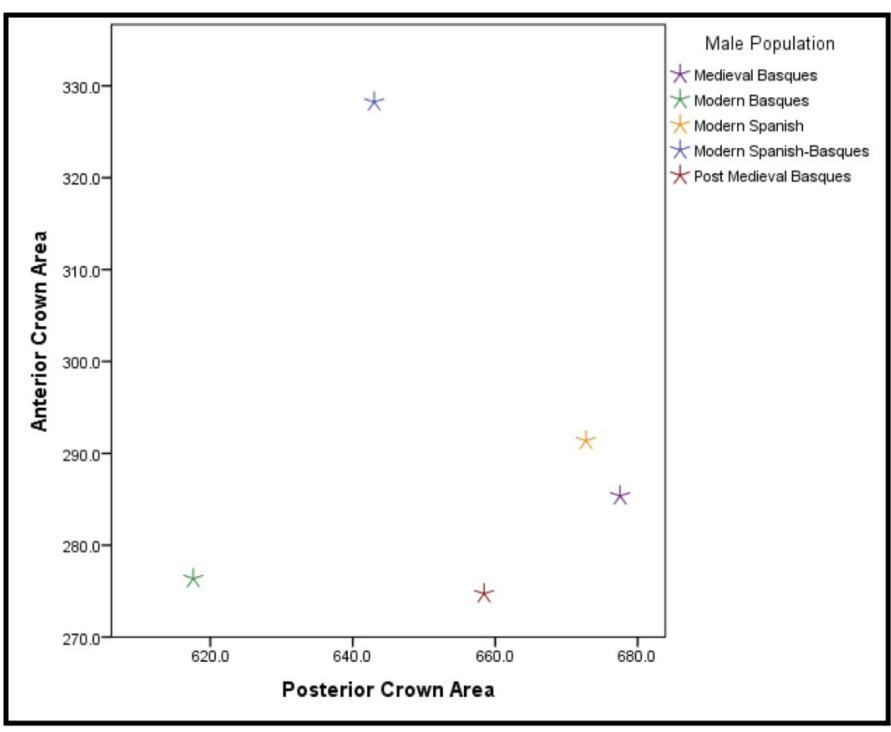

Figure 1. Anterior and posterior crown areas showing temporal change in tooth size for male samples.

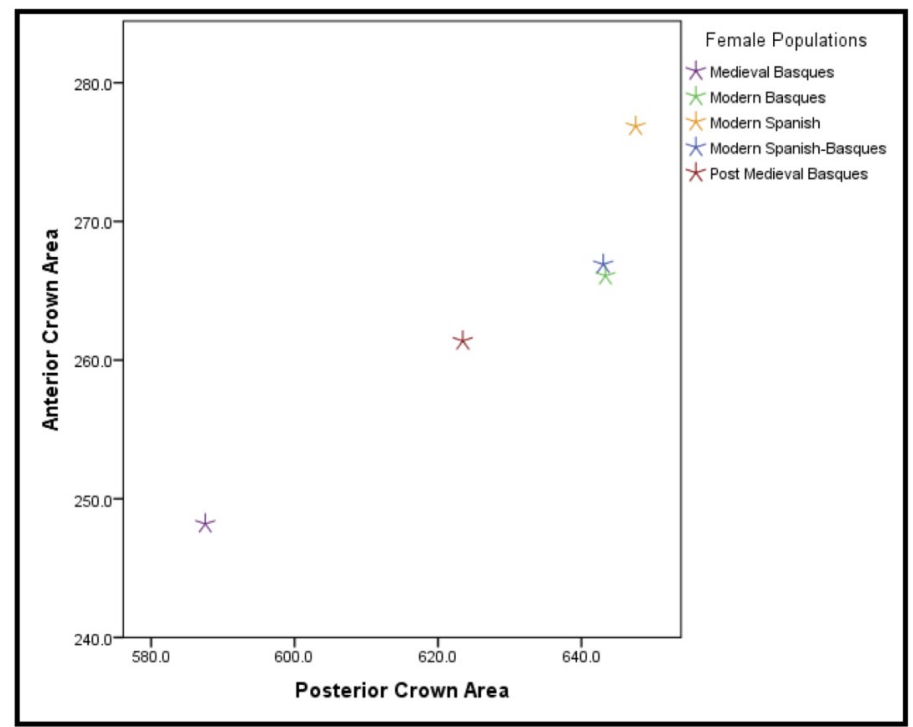

Figure 2. Anterior and posterior crown areas showing temporal change in tooth size for female samples. diately. Modern Basques show the least divergences from the predicted dental size (Figure 3). Residual scores were then visualized through a Ward's dendrogram to view how Western European populations grouped based on tooth apportionment. In the male samples, modern Basques group with ancient Greeks and medieval Norwegians, while the medieval and post medieval Basques group clustered with NP Lapps and Coimbra samples (Figure 4).

Male world residual scores showed similar patterns to those observed within Western Eurasia when looking at all MD and BL measurements. The Basque samples show similar apportionment to each other, as well to the Coimbra and Ainu samples (Figure 5). In the male residual dendrogram for world populations (Figure 6), the medieval and post medieval Basques group near each other and the medieval Norwegian samples, as well as the Portuguese Coimbra sample; modern Basques group near ancient and modern Greeks, Jomon, South African Blacks, India, and Tibet.
As seen in the Western Eurasian male residual scores, the female Portuguese Coimbra sample, shows the greatest divergence from the predicted size of the dentition, followed by the medieval Basques, NP Lapps, and medieval Norwegians, respectively (Figure 7). Again, the post medieval Basques fall in between the medieval and modern Basque scores. When viewing residual scores through dendrograms, the modern samples and post medieval Basques group with Greek populations, and the medieval Basques group with Coimbra and NP Lapps (Figure 8). Many of the patterns observed in the Western Eurasian groupings are also reflected in residual scores for female world samples (Figure 9), as the medieval and post medieval Basque samples group with other Western Eurasian populations, Greeks, Coimbra, and NP Lapps, with two additional samples, the Ainu and the Griqua. The modern Basque sample aligns with populations that create a geographically isolated grouping that includes the San, India, Jomon, and the Philippines (Figure 10). 


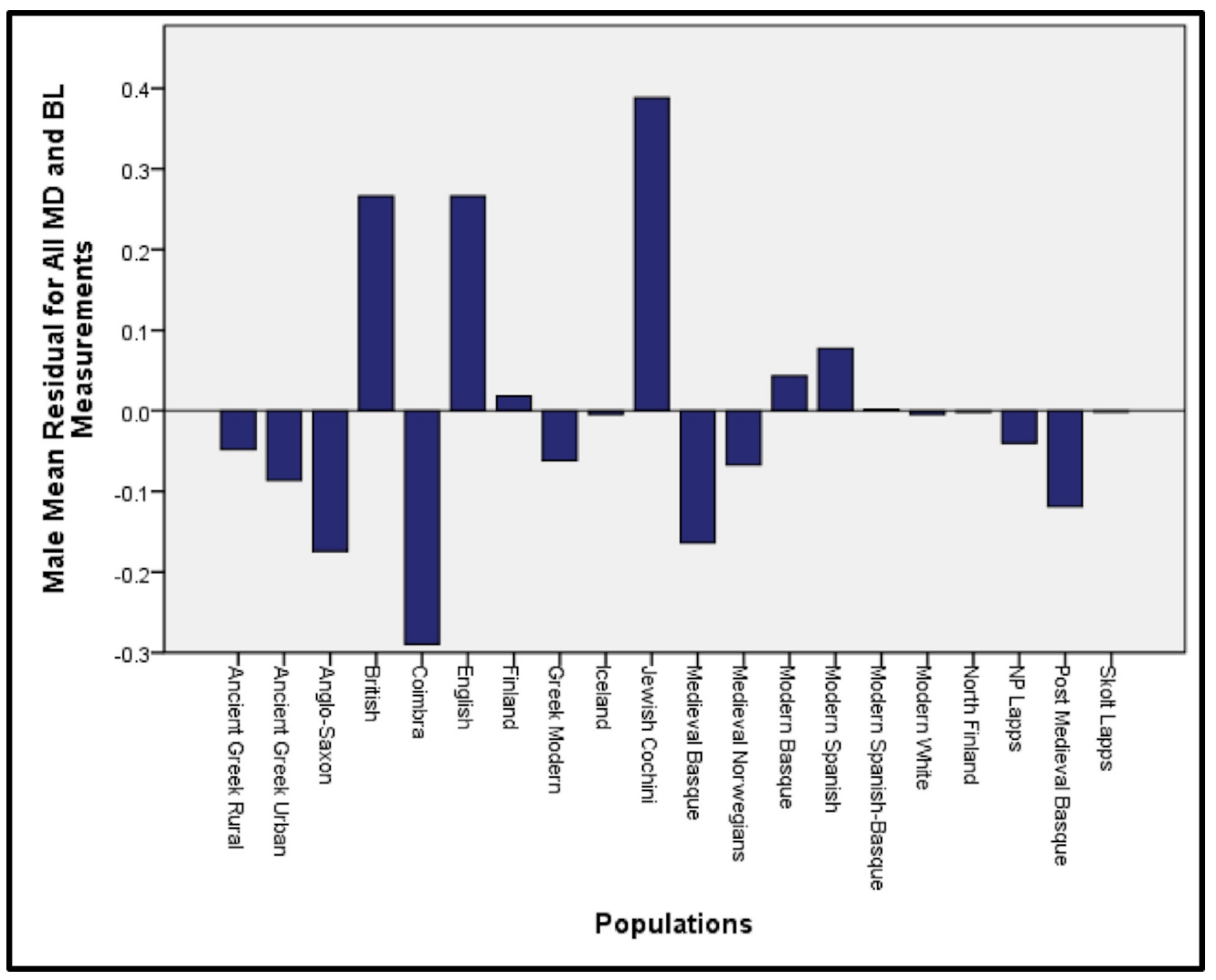

Figure 3. Residual factor graph plotting the residual of anterior MD and BL measurements for Western Eurasian male populations.

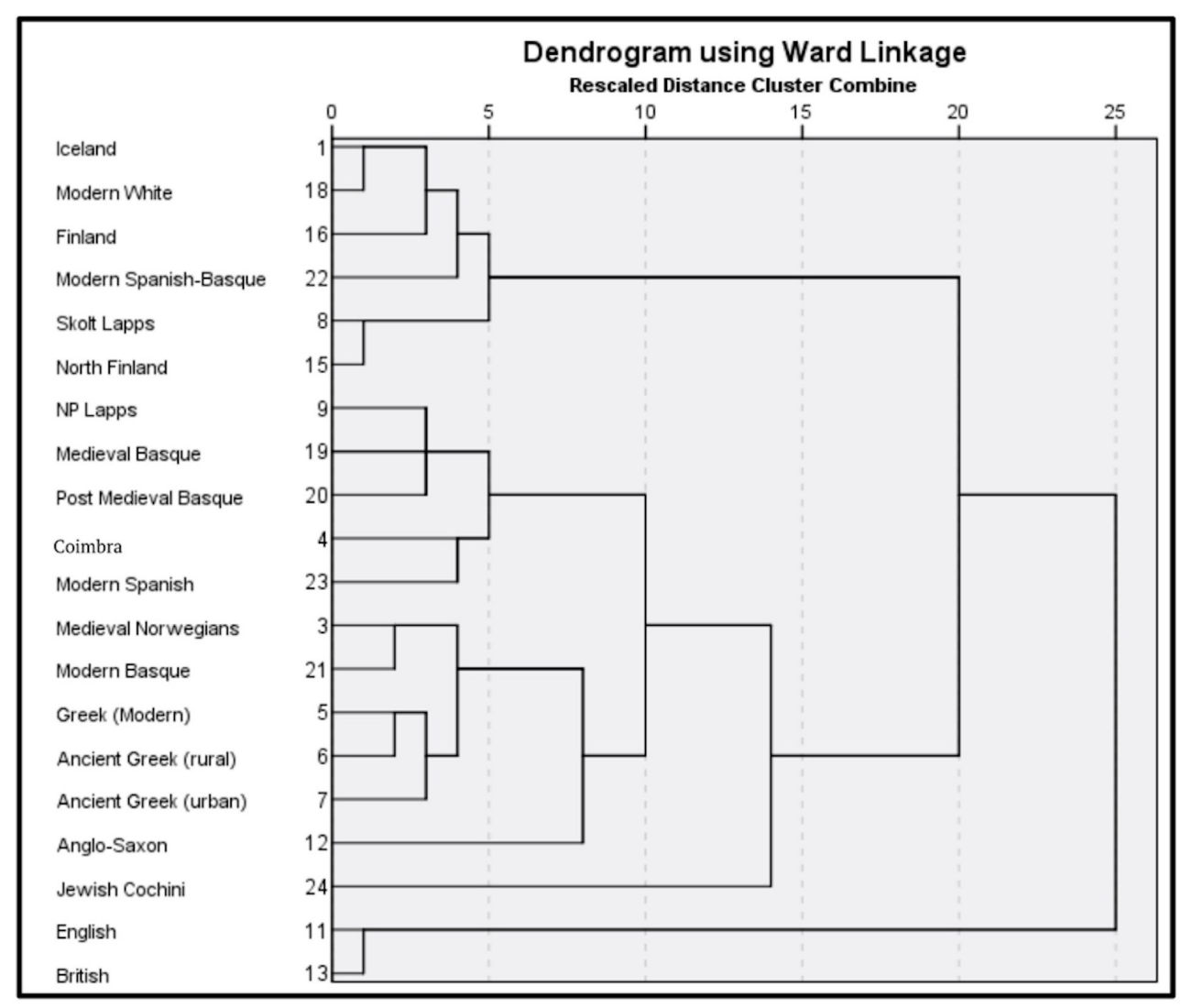

Figure 4. Ward's (1963) Dendrogram based on residual scores of all MD and BL measurements for Western Eurasian Male populations. 


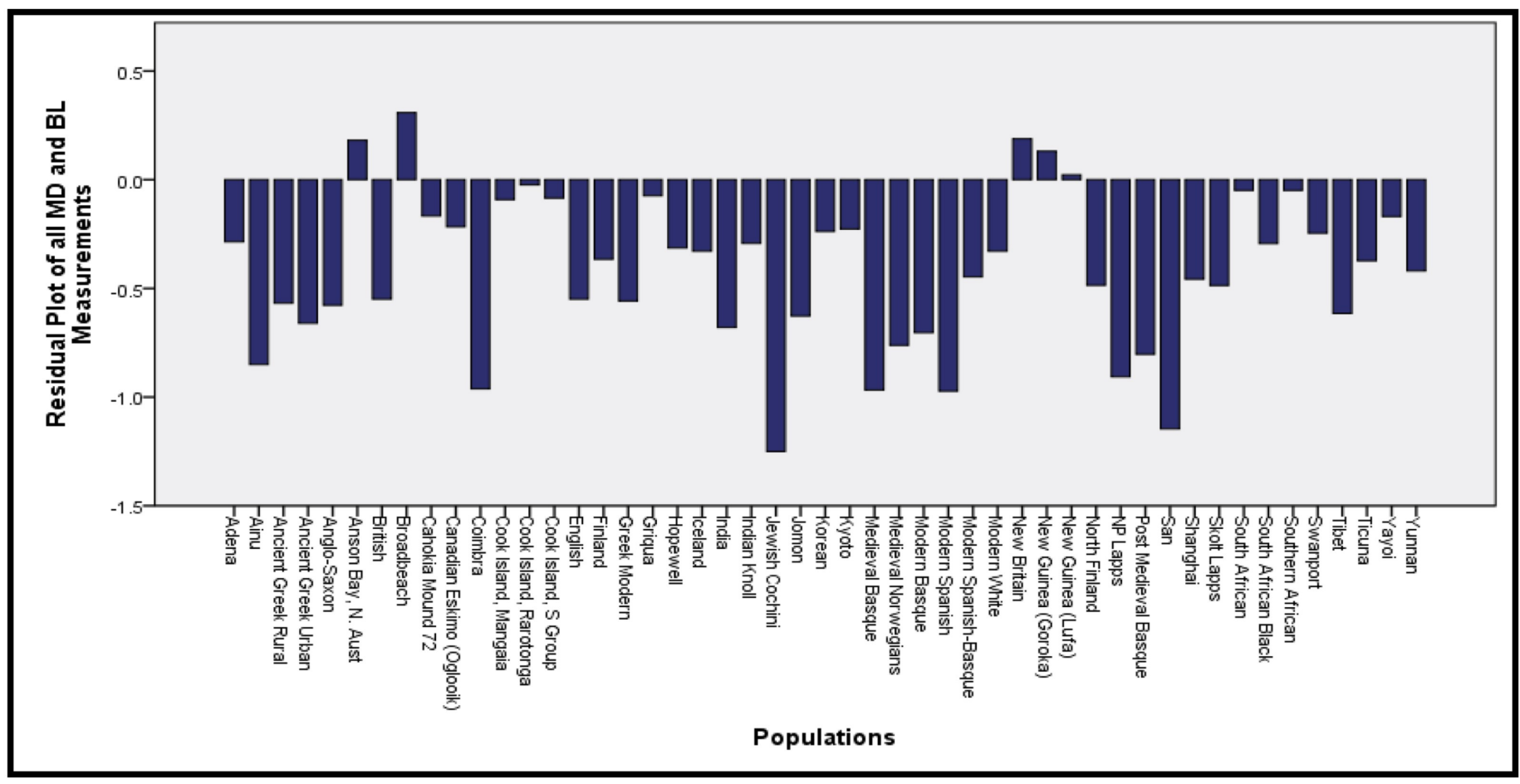

Figure 5. Residual Factor Graph plotting the residual of all MD and BL measurements for World Male populations.

Viewing MD and BL measurements for world male samples using PCA in a dendrogram, clear geographic separations emerge (Figure 11). Distinctions between Sahul-Pacific and Sunda-Pacific are clearly seen. Sunda-Pacific and Sino-American are more mixed, yet still lie in the first branch of the dendrograms separating these groups from the Western Eurasian groups which diverged in the lower branch. The medieval Basque samples again group with their Coimbra neighbors, post medieval Basque samples grouped together with NP Lapps, medieval Norwegians, South Africa, and Ainu. Residual scores show modern Basques align with other small-toothed groups (Greeks, AngloSaxons, and English). Much like males, female world population samples show the same distinctions between the geographical regions (Figure 12). Ainu, medieval Norwegians, NP Lapps, Griqua, and Coimbra align with the medieval and post medieval Basque samples. The medieval Basque sample show the closest apportionment to Coimbra, representing the Iberian Peninsula. Modern Basques grouped with India, Jomon, South Africa, and British samples.

\section{Discussion}

Though genetic studies suggest increased movement into the Basque Country during post medieval times, the overall distinct phenotype of the modern Basque population is still evident when compared to geographically proximate populations. When viewing Basque variation in the context of other Western Eurasian groups, interesting patterns emerge. Medieval Basques consistently group within Western European populations, most often with Coimbra, their Portuguese neighbors. Post medieval and modern samples grouped with the NP Lapps, medieval Norwegians, and the Greeks, both ancient and modern. This grouping of Basque samples with these samples is consistent with their isolated status. NP Lapps differentiate at a high level because, like the Basques, they are geographically removed and linguistically distinct (Uralic language family vs. Indo-European) from other Western Europeans. This uniqueness has been suggested to be related to a Paleolithic origin of the Lapps (Cavalli-Sforza et al., 1994). The pattern of Basques grouping with other geographically and linguistically isolated Western European populations is also seen in genetic (Azualde et al. 2005; Azualde et al. 2006; Martinez-Cruz et al., 2012), and dental studies, both in terms of morphology (Scott et al., 2013) and metrics.

Given that Basques align with other geographically and linguistically isolated populations, rather than more neighboring European and North African populations, this could support the longheld position that they represent a continuous settlement in the Pyrenees since the Paleolithic followed by relative genetic isolation, while still al- 
South African

Southern African

Cook Island, Rarotonga

Cook Island, S Group

Cook Island, Mangaia

\section{Griqua}

Cook Island, Pukapuka

\section{Yuendumu}

New Guinea (Lufa)

Anson Bay, N. Aust

New Britain

Kalumburu

New Guinea (Goroka)

Broadbeach

Skolt Lapps

North Finland

Modern Spanish-Basque

Shanghai

Yunnan

Fukuoka

Glacial Kane

Ticuna

Finland

Yang Shao Neolithic

Indian Knoll

South African Black

Canadian Eskimo (HB)

Adena

Iceland

Modern White

Xi Shang Neolithic

Hopewell

rayoi

Cahokia Mound 72

Korean

Swanport

Kyoto

Canadian Eskimo (Oglooik)

English

British

Greek Modern

Ancient Greek Rural

Anglo-Saxon

Jomon

Tibet

Incia

South African Black, Contemp.

Modern Basque

Ancient Greek Urban

Jewish Cochini

San

Medieval Basque

Modern Spanish

Coimbra

Medieval Norwegians

Past Medieval Basque

NP Lapps

Ainu

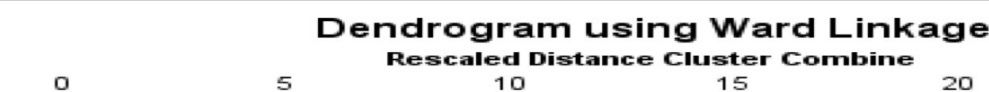

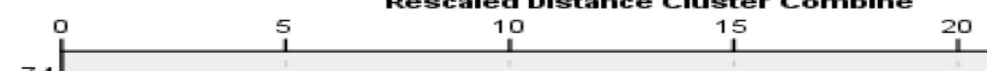

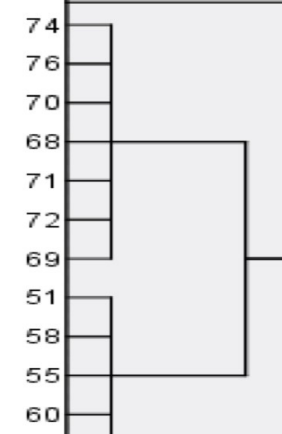

.

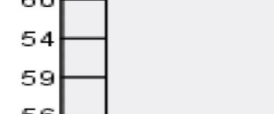

59
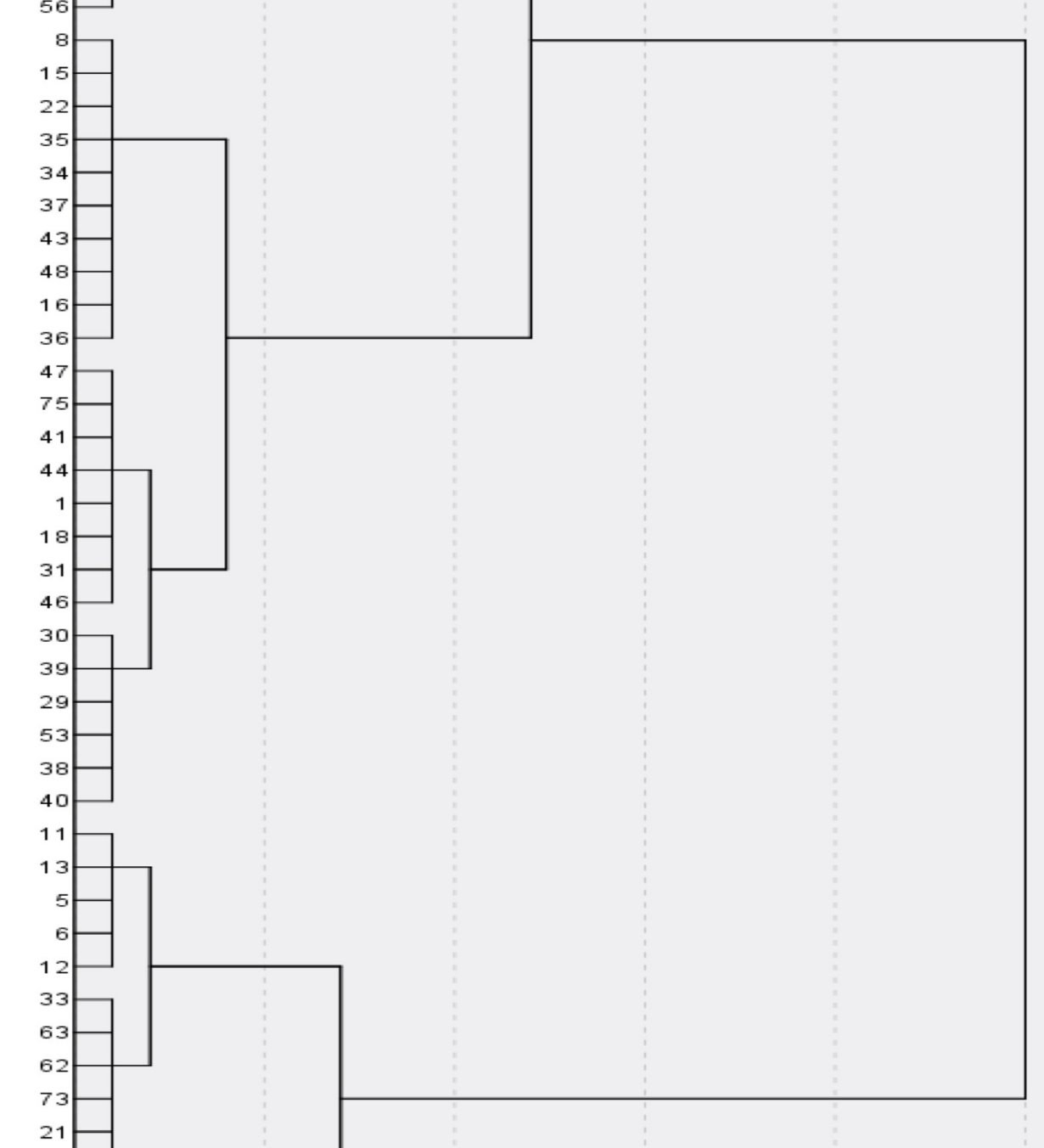

Figure 6. Dendrogram plotting the residual of all MD and BL measurements for World Male populations. 


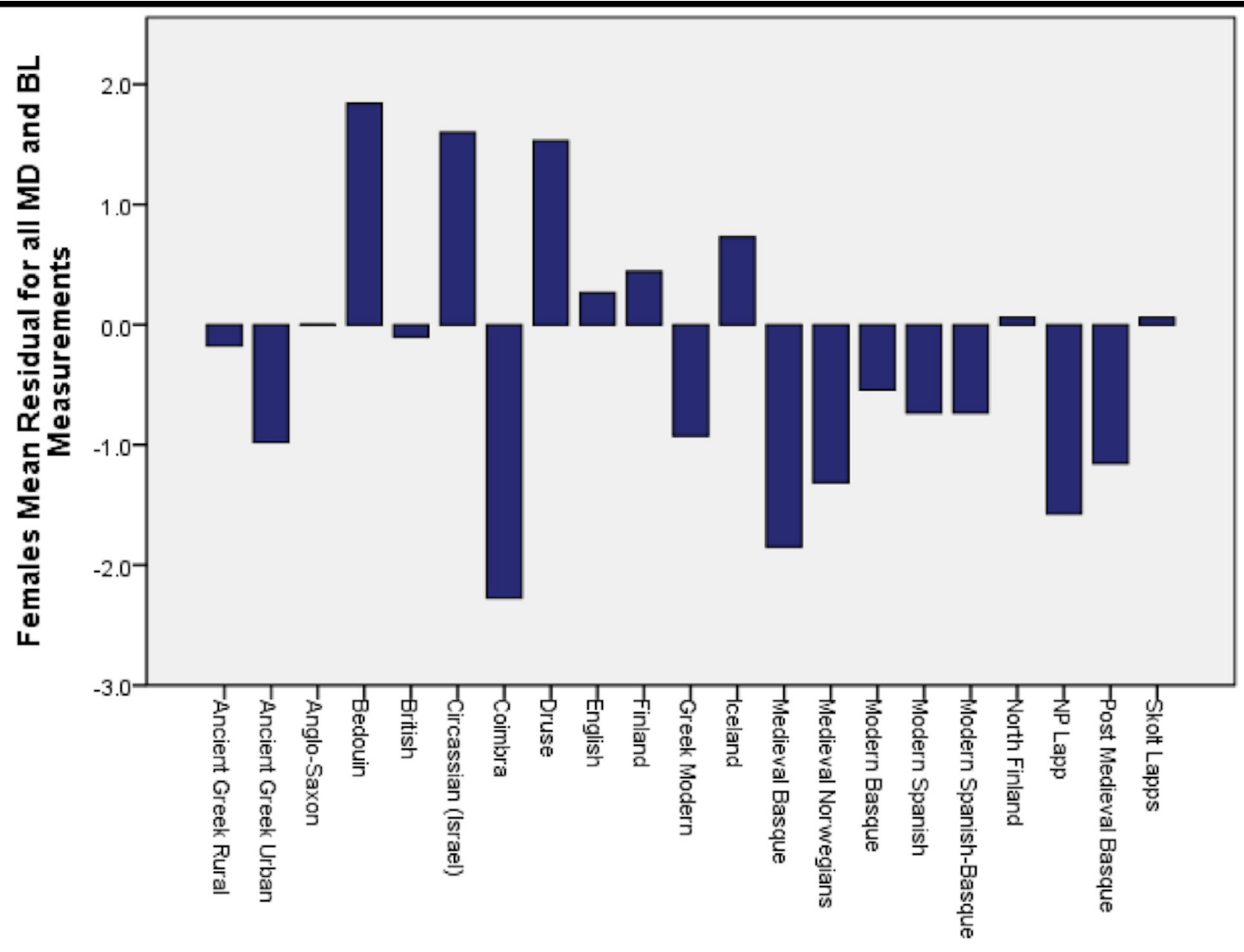

Populations

Figure 7. Residual Factor Graph plotting the residual of all MD and BL measurements for Western Eurasian Female populations.

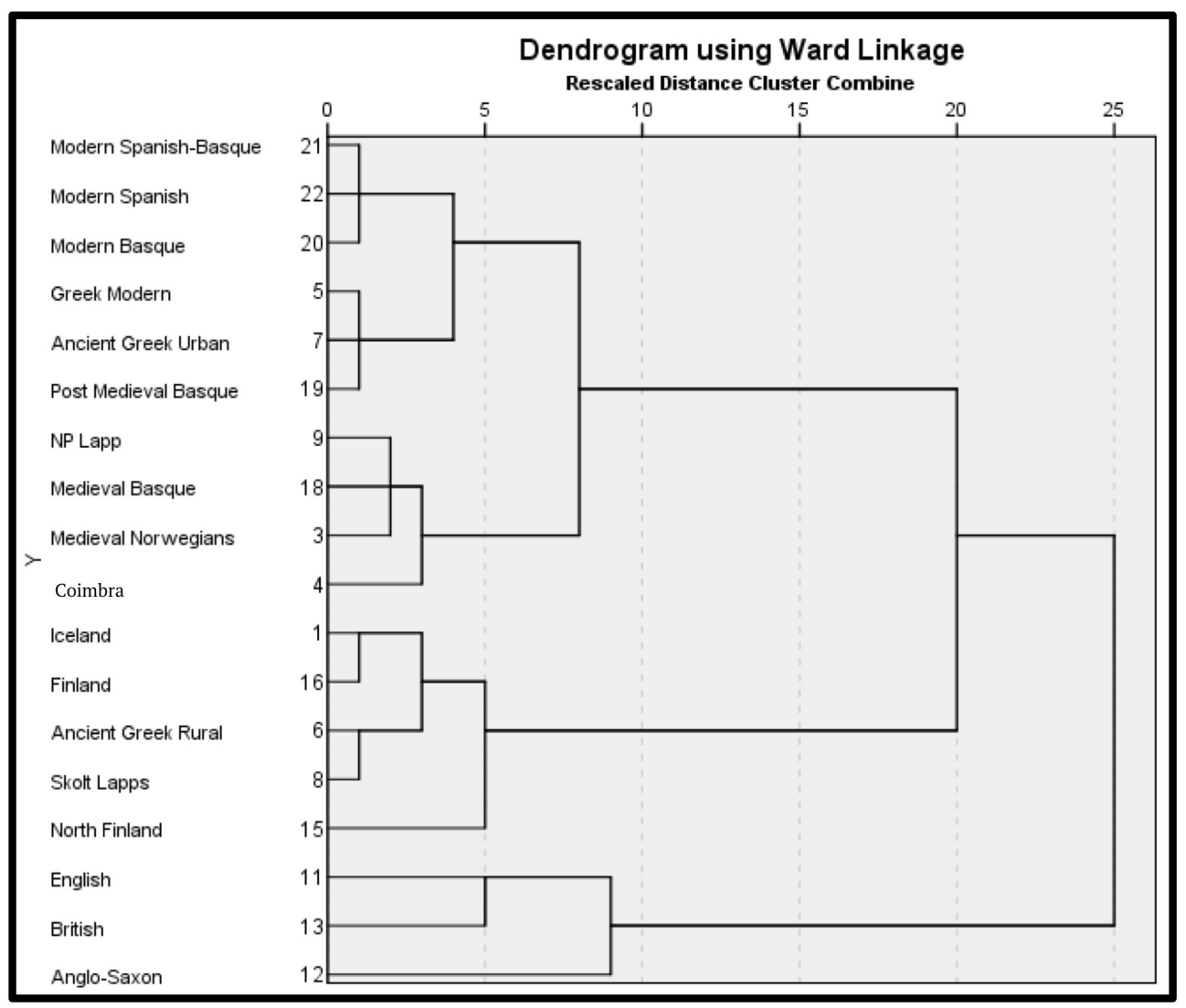

Figure 8. Ward's (1963) Dendrogram based on residual scores of all MD and BL measurements for Western Eurasian Female populations. 


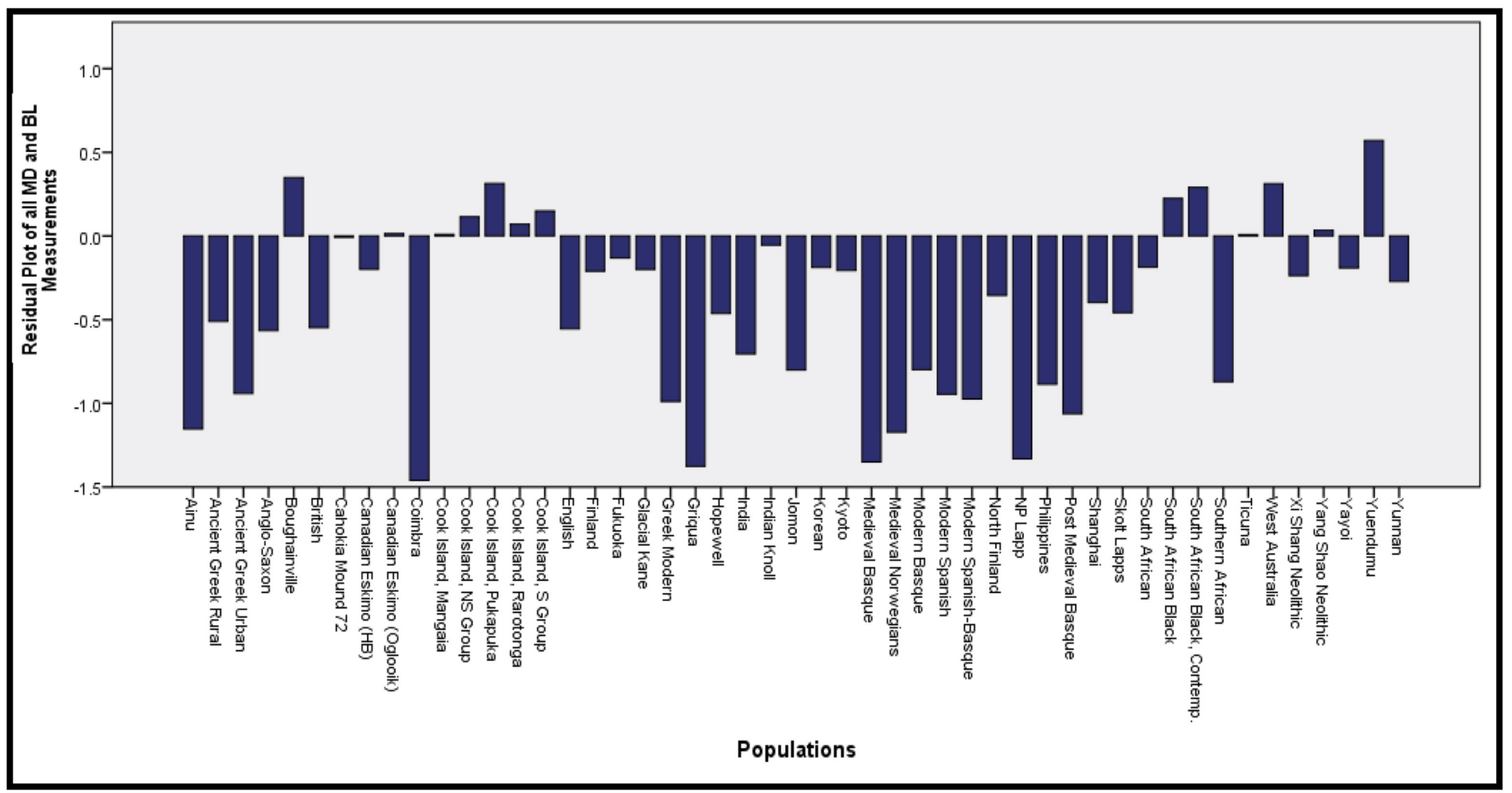

Figure 9. Residual Factor Graph plotting the residual of all MD and BL measurements for World Female populations.

lowing for recent gene flow from Iberian and/or North African groups.

Using dental metrics to view the Basques on a worldwide scale, they do remain distinct. There are clear separations between world regions, with Western Eurasia separating on its own branch. Medieval and post medieval Basque samples do, however, group with other distinct groups, including Coimbra, NP Lapps, medieval Norwegians, and somewhat surprisingly, the Ainu. The modern Basque samples showed similar patterns, as they grouped with small-toothed Western European populations (British and Greeks), but they also group more frequently with non-European populations, such as India, Griqua, and the Jomon.

The medieval and post medieval samples show a more consistent grouping within Western Europe, whereas modern Basques were more likely to group with outside populations within the Western Eurasia branch. The differences between the modern samples and those from the preceding periods (i.e. medieval and post medieval) might be explained by the overrepresentation of females in the modern sample, ethnic self-identification, or to disparities between measurements taken directly from the teeth of the two skeletal samples and those taken from dental casts of the modern sam- ple. It is very likely that the modern Basque sample is representative of a more genetically diverse population in comparison to the earlier skeletal samples.

Focusing on medieval and post medieval Basques, there is a pattern of grouping with Western Eurasian samples in general, and with outliers in particular. These consistent groupings could further provide support that the Basque population has a deep history in Western Europe, one that precedes by millennia the influx of Indo-European farmers from the Middle East and Anatolia (Cavalli-Sforza, 1994; Izagirre et al., 2001).

\section{Conclusions}

Basques are an anthropologically significant population due to their antiquity and genetic isolation in the Pyrenees mountains of northern Spain and southern France. A better understanding of this population would help to provide greater insights into the movement and interaction of human populations in Europe.

As genetic (Azualde et al. 2005; Azualde et al. 2006; Martinez-Cruz et al. 2012) and dental studies show (Scott et al. 2013), the Basques are a Western Eurasian population, yet they fall outside this broader population grouping, often clustering with 
India

India

Modern Basque

Jomon

Philippines

Southern African

Ancient Greek Urban

Modern Spanish

Greek Modern

Modern Spanish-Basque

Medieval Norwegians

Ainu

Post Medieval Basque

NP Lapp

Medieval Basque

Griqua

Coimbra

Cook Island, NS Group

Cook Island, S Group

South African Black

West Australia

Cook Island, Pukapuka

South African Black, Contemp.

Boughainville

$>$

Yuendumu

English

British

Anglo-Saxon

Ancient Greek Rural

Skolt Lapps

Hopewell

North Finland

Shanghai

Xi Shang Neolithic

Yunnan

Korean

South African

Yayoi

Canadian Eskimo (HB)

Glacial Kane

Finland

Kyoto

Indian Knoll

Fukuoka

Ticuna

Cook Island, Mangaia

Canadian Eskimo (Oglooik)

Cahokia Mound 72

Yang Shao Neolithic

Cook Island, Rarotonga

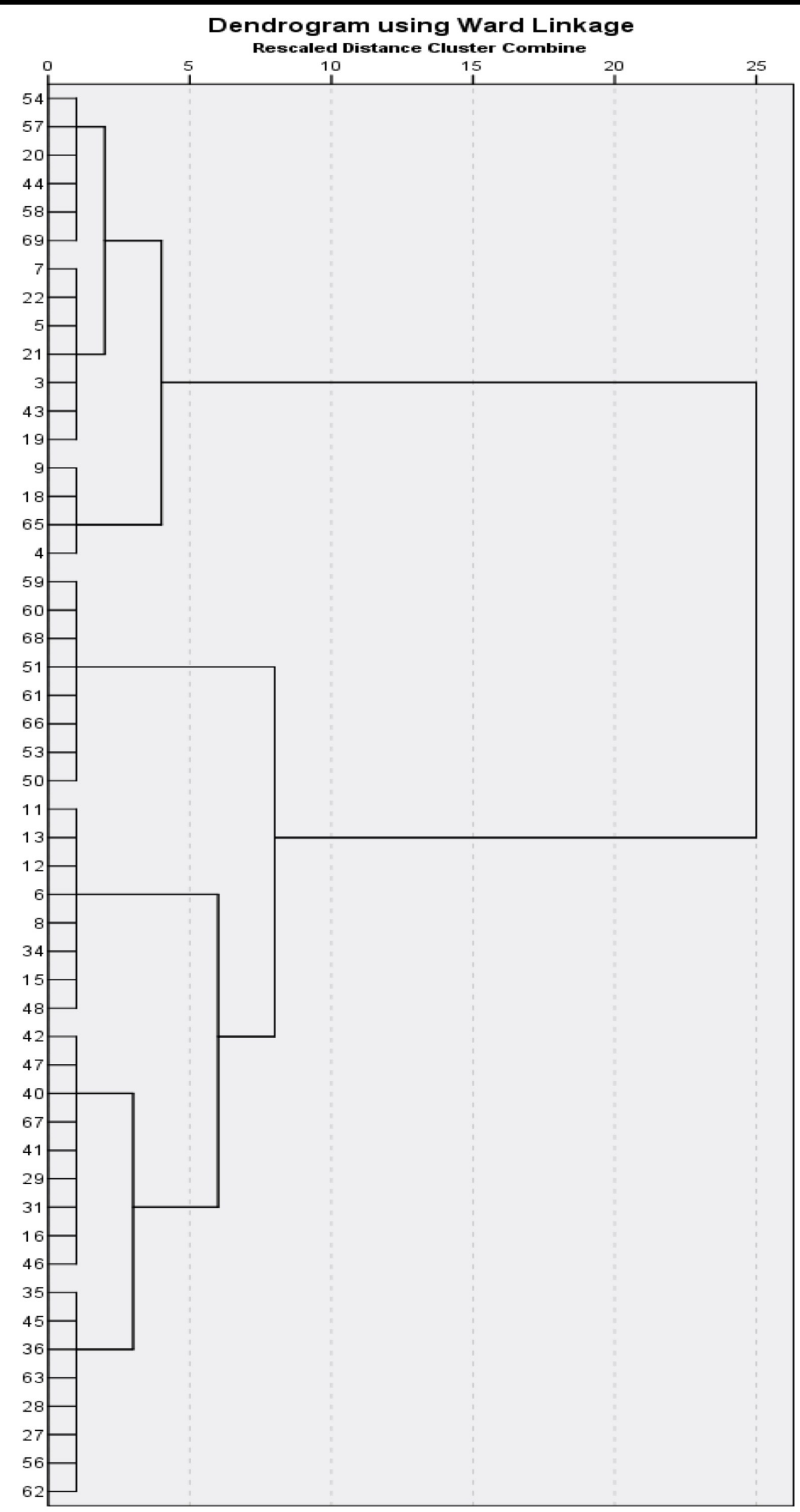

Figure 10. Dendrogram plotting the residual of all MD and BL measurements for World Female populations. 


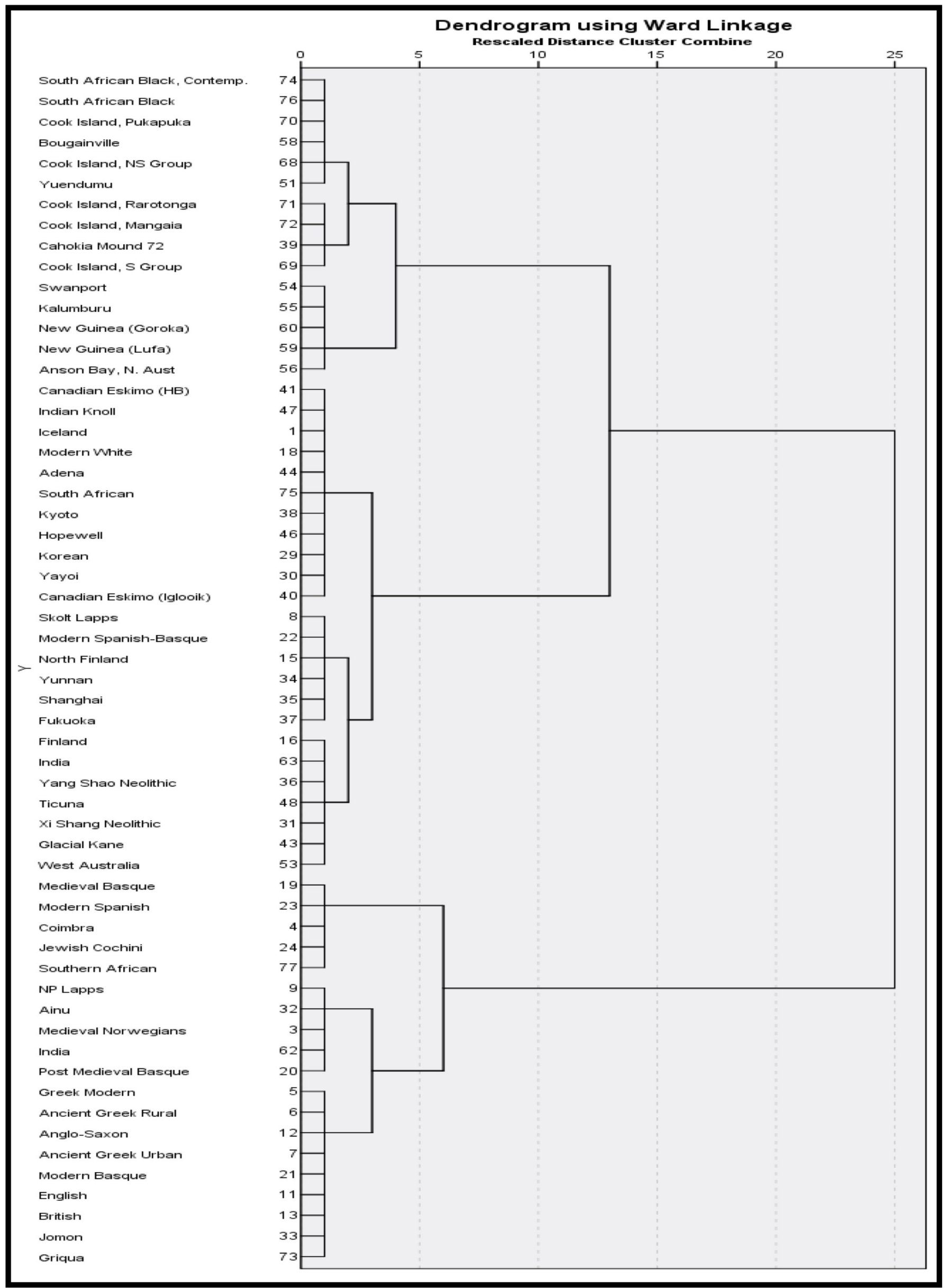

Figure 11. Dendrogram plotting the first PCA score of all MD and BL measurements for World Male populations. 
Incia

India

Modern Basque

Southern African

Jomon

British

Greek Modern

Ancient Greek Urban

Modern Spanish-Basque

Modern Spanish

Philippines

Post Medieval Basque

Ainu

Medieval Norwegians

NP Lapp

Griqua

Medieval Basque

Coimbra

Cook Island, NS Group

Cook Island, S Group

West Australia

Bougainville

South African Black

Cook Island, Pukapuka

South African Black, Contemp.

$>$ Yuendumu

North Finland

Shanghai

Hopewell

Ancient Greek Rural

Anglo-Saxon

English

Skolt Lapps

Cahokia Mound 72

Cook Island, Rarotonga

Canadian Eskimo (Igloolik)

Ticuna

Indian Knoll

Cook Island, Mangaia

Yang Shao Neolithic

Canadian Eskimo (HB)

Xi Shang Neolithic

Korean

Finland

Kyoto

Yunnan

Yayoi

South African

Glacial Kane

Fukuoka

Iceland
Dendrogram using Ward Linkage

Rescaled Distance Cluster Combine
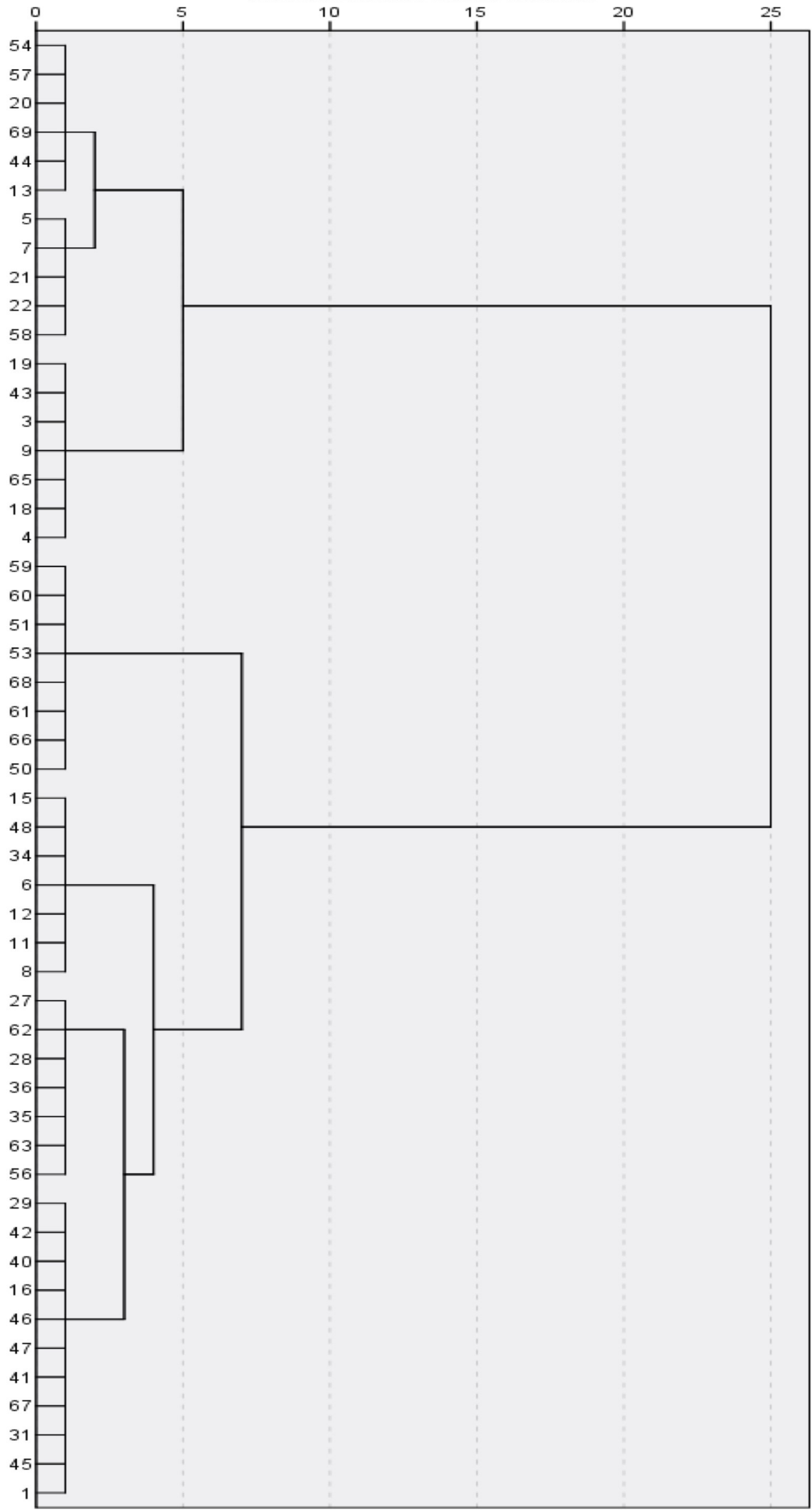

Figure 12. Dendrogram plotting the first PCA score of all MD and BL measurements for World Female populations. 
non-European populations. While genetic isolation played a major role in the genetic make-up of the Basques, there is evidence of gene flow between Basques and linguistically and culturally different surrounding populations, specifically the Spanish and North Africans (Azualde et al. 2005; Azualde et al. 2006; Martinez-Cruz et al. 2012). Though gene flow is evident, it does not mask the uniqueness of Basque genetics, be it in blood groups, mtDNA, Y chromosomes, or dental morphometrics.

Geographic and linguistic barriers could be major factors in the isolation of the Basques in prehistoric times, though these would have been barriers more easily crossed in historic times, as evidenced by genetic studies. This research supports the idea that the Basques are one of the oldest populations in Europe. Their subsequent isolation throughout prehistoric times appears to have preserved their unique genetic heritage. Interestingly, increased gene flow in later periods does not correspond with stronger connections with other Western European populations in terms of dental metrics.

\section{Acknowledgements}

This article is based upon a Master's thesis carried out by the first author and supervised by the third author. Access to the living and skeletal collections in Bilbao and Vitoria were facilitated by Professor Conchita de la Rúa who is acknowledged for her kind assistance. Professor Augustin Azkarate Garai -Olaun generously allowed the third author to make observations on the large and unique collection of skeletons at the Catedral de Santa María in Vitoria, Spain. The insightful comments from Dr. Sebastian Varela Fontecha in editing and proofreading this article are gratefully acknowledged.

\section{REFERENCES}

Acharya, A.B., Prabhu S., \& Muddapur, M.V. (2011). Odontometric sex assessment from logistic regression analysis. International Journal of Legal Medicine, 125, 199-204.

Alberdi, F., Allison, C., Blumberg, B.S., Ikin, E.W., \& Mourant, A.E. (1957). The blood groups of the Spanish Basques. Journal of the Royal Anthropological Institute, 87, 217-221.

Alfonso-Sánchez, M.A., Cardoso, S., Martínez-

Bouzas, C., Peña, J.A., Herrerra, R.J., Castro, A., Fernández-Fernández, I., \& de Pancorbo, M.M. (2008). Mitochondrial DNA haplogroup diversity in Basques: a reassessment based on HVI and HVII polymorphisms. American Journal of Human Biology, 20, 154-164.
Alonso, S., Flores, C., Cabrera, V., Alonso, A., Martín, P., Albarrán, C., Izagirre, N., de la Rúa, C., \& García, O. (2005). The place of the Basques in the European Y-chromosome diversity landscape. European Journal of Human Genetics, 13,1293-1302. Alvesalo, L. (1985). Dental growth in 47 XYY males and in conditions with other sex chromosome anomalies. In: Sandberg A.A., editor. The Y Chromosome, part B: clinical aspects (pp. 277-300). New York: Alan R. Liss.

Alzualde, A., Izaguirre, N., Alonso, S., Alonso, A., \& de la Rúa C. (2005). Temporal mitochondrial DNA variation in the Basque Country: influence of Post-Neolithic events. Annals of Human Genetics, 69, 665-679.

Alzualde, A., Izaguirre, N., Alonso, S., Alonso, A., Albarrán, C., Azkarate, A., \& de la Rúa, C. (2006). Insights into the "isolation' of the Basques: $\mathrm{mtD}$ NA lineages from the historical site of Aldaieta. American Journal of Physical Anthropology, 130, 394 -404 .

Axelsson, G., \& Kirveskari, P. (1983). Crown size of permanent teeth in Icelanders. Acta Odontologica Scandinavica, 41, 181-6.

Bailit, H.L., \& Friedlander, J.S. (1966). Tooth size reduction: a hominid trend. American Anthropologist, 68, 665-672.

Barnes, D.S. (1969). Tooth morphology and other aspects of the Teso dentition. Am American Journal of Physical Anthropology, 30, 183-194.

Barrett ,M.J., Brown, T., \& MacDonald, M.R. (1963). Dental observations on Australian Aborigines: MD diameters of deciduous and permanent teeth. Australian Dental Journal, 8,150-155.

Barrett ,M.J., Brown, T., \& MacDonald, M.R. (1964). Dental observations on Australian Aborigines: BL diameters of deciduous and permanent teeth. Australian Dental Journal, 9, 280-328.

Beyer-Olsen, E.M.S., \& Alexandersen, V. (1995). Sex assessment of medieval Norwegian skeletons based on permanent tooth crown size. International Journal of Osteoarchaeology, 5, 274-281.

Brace, C.L. (1976). Krapina 'classic' Neanderthals and the evolution of the European face. Journal of Human Evolution, 21, 141-153.

Brace, C.L. (1978). Tooth reduction in the Orient. Asian Perspect, 19, 203-219.

Brace, C.L., \& Ryan, A.S. (1980). Sexual dimorphism and human tooth size differences. of $\mathrm{Hu}$ man Evolution, 9, 417-435.

Brace, C.L., Hinton, R.J., Brown, T., Green, R.C., Harris, E.F., Jacobson, A., Meiklejohn, C., Mizoguchi, Y., Xiang-qing, S., Smith, P., Smith, R.J., Specht, J., Terrell, J., \& White, J.P. (1981). Ocean 
tooth size variation as a reflection of biological and cultural mixing [and comments and reply]. Current Anthropology, 22, 549-569.

Brace, C.L., \& Nagai, M. (1982). Japanese tooth size, past and present. American Journal of Physical Anthropology, 59, 399-411.

Brace, C.L., Xiang-Qing, S., \& Zhen-Biao, Z. (1984). Prehistoric and modern tooth size in China. In: Smith, F.H., \& Spencer, F., editors. The origins of modern humans: A world survey of the fossil evidence (pp. 485-516). New York: Alan Liss.

Brace, C.L. (2000). Reflections on the face of Japan: multivariate craniofacial and odontometric perspective. In: Brace C.L., editor. Evolution in an anthropological view (pp. 249-282). Altamira Press.

Buikstra, J. E., \& Ubelaker, D. H. (1994). Standards for data collection from human skeletal remains. Proceedings of a seminar at the Field Museum of Natural History Fayetteville Arkansas Archaeological Survey (44).

Campbell, T.D. (1925) Dentition and palate of the Australian Aboriginal. University of Adelaide, The Hassell Press.

Cavalli-Sforza, L.L., Menozzi, P., \& Alberto, P. (1994). The history and geography of human genes. Princeton: Princeton University Press.

Cavalli-Sforza, L.L. (1997). Genetic and cultural diversity in Europe. Journal of Anthropological Res,earch 53, 383-404.

Cavalli-Sforza, L.L. (2000). Genes, people, and languages. Berkley: University of California Press.

Chalmers, J.N.M., Ikin, E.W., \& Mourant, A.E. (1949). The ABO, MN, and Rh blood groups of the Basque people. American Journal of Physical Anthropology, 7, 529-544.

Drennan, M.R. (1929). The dentition of the Bushman tribe. Annals South African Mus, 29, 151-250.

Freedman, L., \& Lofgren, M. (1981). Odontometrics of Western Australian Aborigines. Archaeology in Oceania, 16, 87-93.

Galera, V., \& Cunha, E. (1993). Dental patterns of Coimbra population. Anthropologie, 31, 35-44.

Garn, S.M., Lewis, A.B., Swindler, D.R., \& Kerewsky R.S. (1967b). Genetic control of sexual dimorphism in tooth size. J Dent Res, 46, 963-972.

Harris, E.F., \& Nweeia, M.T. (1980b). Tooth size of Ticuna Indians, Columbia, with phonetic comparisons to other Amerindians. American Journal of Physical Anthropology, 53, 81-91.

Harris, E.F., \& Rathbun, T.A. (1991). Ethnic differences in the apportionment of tooth sizes. In: Kelley, M.A., \& Larsen, C.S, editors. Advances in Dental Anthropology (pp. 121-142). Wiley
Liss Inc.: New York, NY.

Harris, E.F. (1997). A strategy for comparing odontometrics among groups. Dental Anthropology, 12, 1-5.

Harris, E.F., Potter, E.H., \& Lin, J. (2001). Secular trend in tooth size in urban Chinese assessed from two-generation family data. American Journal of Physical Anthropology, 115, 312-318.

Harris, E.F. (2003). Where's the variation? Variance components in tooth size of the permanent dentition. Dental Anthropology, 16, 84-94.

Harris, E.F. (2008). Statistical applications in dental anthropology. In: Irish J.D., and Nelson G.C., editors. Technique and application in dental anthropology (pp 35-67). Cambridge University Press.

Henneberg, R.J. (2011). Dental health and affiliations of inhabitants of the ancient Greek colony in Metaponto, Italy (6th-3rd century BC). Dissertation, University of Witwatersrand, Johannesburg.

Hinton, R.J., Smith, M.O., \& Smith, F.H. (1980). Tooth size changes in prehistoric Tennessee Indians. Hum Biol, 52, 229-245.

Hopkinson, K.A. (2009). Dental Health of the Santa Maria Cathedral Burial Population (12-19th Century), Vitoria-Gasteiz, Spain. Thesis, University of Nevada, Reno.

Hopkinson, K.A., Yeats, S.Y., \& Scott, G.R. (2008). For whom the coin tolls: green stained teeth in Medieval and Post-Medieval Spanish burials. Dental Anthropology, 21,12-17.

Hurles, M.E., Veitia, R., Arroyo, E., Armenteros, M., Bertranpetit, J., Pérez-Lezaun, A., Bosch, E., Shlumukova, M., Cambon-Thomsen, A., McElreavey, K., López de Munain, A., Röhl, A., Wilson, I.J., Singh, L., Pandya, A., Santos, F.R., Tyler-Smith, C., \& Jobling, M.A. (1999). Recent male-mediated gene flow over a linguistic barrier in Iberia suggested by analysis of a Y-chromosome DNA polymorphism. American Journal of Human Genetics, 65, 14371448.

IBM Corp. (2013). IBM SPSS Statistics for Windows, Version 22.0. IBM Corp: Armonk, NY.

Iscan, M.Y. (1989). Reconstruction of life from the skeleton. New York: Liss.

Izagirre, N., Alonso, S., \& de la Rúa, C. (2001). DNA analysis and the evolutionary history of the Basque population: a review. Journal of Anthropological Research, 57, 325-344.

Jacobson, A. (1982). The dentition of the South African Negro. Higginbotham, Inc.

Janzen, J.J. (2011). A craniometric analysis of Basque skulls from the Cathedral of Santa Maria, Vitoria- 
Gasteiz: Biological distance and population history. Thesis, University of Nevada Reno.

Kachigan, S.K. (1986). Statistical analysis: An interdisciplinary introduction to univariate and multivariate methods. New York: Radius Press.

Kieser, J.A. (1985). An odontometric analysis of early Griqua dentition. Anthropologischer Anzeiger, 43, 51- 58.

Kieser, J.A., Groeneveld, H.T., \& Preston, C.B. (1985e). A metrical analysis of the South African Caucasoid dentition. Journal of the Dental Association of South Africa, 40, 121-5.

Kieser, J.A., Groeneveld, H.T., \& Cameron, N. (1987). Evidence for a secular trend in the Negro dentition. Annals of Human Biology 14, 517-32.

Kieser, J.A. (1990). Human adult odontometrics. Cambridge University Press.

Kirveskari, P., Hansson, H., Hedegard, B., \& Karlson, N. (1977). Crown size and hypodontia in the permanent teeth of modern Skolt Lapps. American Journal of Physical Anthropology, 48, 107 $-12$.

Koyoumdjisky-Kaye, E., Zilberman, Y., \& Hazan, O. (1977). A comparative study of tooth and dental arch dimensions and sexual dimorphism in Israeli children of Cochin and North African descent. Zeitschrift für morphologie und anthropologie, 69, 32-42.

Lavelle, C.B.L. (1968). Anglo-Saxon and modern British teeth. Journal of Dental Research, 47, 811815.

Lukacs, J.R. (1985). Tooth size variation in prehistoric India. American Anthropologist, 87, 811-825.

Martinez-Crus, B., Harmant, C., Platt, D.E., Wolfgang, H., Manry, J., Ramos-Luis, E., Soria Heranz, D.F., Bauduer, F., Salaberria, J., Oyharcabal, B., Quintana-Murci, L., \& Comas, D. (2012). Evidence of Pre-Roman tribal genetic structure in Basques from uniparentally inherited markers. Molecular Biology and Evolution, 29, 2211-2222.

Mayhall, J.T. (1979). The dental morphology of the Inuit of the Canadian Central Artic. Ossa 6, 199218.

Moorrees, C.F.A. (1957). The Aleut Dentition. Cambridge: Harvard University Press.

Nelson, C.T. (1938). The teeth of the Indians of Pecos Pueblo. American Journal of Physical Anthropology, 23, 261- 293.

Pedersen, P.O. (1949). The East Greenland Eskimo dentition, numerical variations and anatomy: a contribution to comparative ethnic odontography. Meddelelser om Grønland, 142, 1-244.

Perzigian, A.J. (1976). The dentition of the Indian
Knoll skeletal populations. American Journal of Physical Anthropology, 47, 63-70.

Perzigian, A.J. (1977). Fluctuating dental asymmetry: variation among skeletal populations. American Journal of Physical Anthropology, 47, 8188.

Perzigian, A.J. (1981). Allometric analysis of dental variation in a human population. American Journal of Physical Anthropology, 54, 341-345.

Perzigian, A.J. (1984). Human odontometric variation: an evolutionary and taxonomic assessment. L'Anthropologie, 22, 193-198.

Phenice, T.W. (1969). An analysis of the human skeletal material from burial mounds in north central Kansas. University of Kansas Press: Lawrence.

Potter, R.H., Nance, W.E., Yu, P., \& David, W.B. (1976). A twin study of dental dimension. Am American Journal of Physical Anthropology, 44, 397 -412 .

Potter, R.H., Nance, W.E., \& Yu P. (1978). Genetic determinants of dental dimension: a twin study. American Journal of Physical Anthropology, 44, 391 $-412$.

Potter, R.H.Y., Alcarzaren, A.B., Herbosa, F.M., \& Tomaneng, J. (1981). Dimensional characteristics of the Filipino dentition. American Journal of Physical Anthropology, 49, 533-44.

Rosenzweig, K.A., \& Zilberman, Y. (1967). Dental morphology of Jews from Yemen and Cochin. American Journal of Physical Anthropology, 26, 1522.

Rosenzweig, K.A., \& Zilberman, Y. (1968). Dentition Bedouin in Israel: I. American Journal of Physical Anthropology, 47, 406-410.

Rosenzweig, K.A., \& Zilberman, Y. (1969). Dentition Bedouin in Israel: II. American Journal of Physical Anthropology, 31, 199-204.

Roychoudhury ,A.K., \& Nei ,M. (1988). Human polymorphic genes: world distribution. New York: Oxford University Press.

Sakai, T., Hanamura, H., \& Ohno, N. (1971). Tooth size of the Pashtun and Tajik in Afghanistan. Journal of the Anthropological Society of Nippon, 79, 159-77.

Sciulli, P.W. (1979). Size and morphology of the permanent dentition in prehistoric Ohio Valley Amerindians. American Journal of Physical Anthropology, 50, 279-84.

Scott, G.R., \& Turner, C.G. (1997). The anthropology of modern human teeth: dental morphology and its variation in recent human populations. New York: Cambridge University Press.

Scott, G.R., \& Gillispie, T.E. (2002). The dentition of prehistoric St. Lawrence Island Eskimos: varia- 
tion, health and behavior. Anthropol Papers Univ Alaska, 2, 50-72.

Scott, G.R., \& Winn, J. (2011). Dental chipping: contrasting patterns of microtrauma in Inuit and European populations. International Journal of Osteoarchaeology, 21, 723-731.

Scott, G.R., \& Poulson, S.R. (2012). Stable carbon and nitrogen isotopes of human dental calculus: a potentially new non-destructive proxy for paleodietary analysis. Journal of Archaeological Science, 39, 1388-1393.

Scott, G.R., Anta, A., Schomberg, R., \& de la Rúa, C. (2013). Basque dental morphology and the "Eurodont" pattern. In: Scott G.R., and Irish J.D., editors. Anthropological perspectives on tooth morphology: genetics, evolution, variation (pp. 296-318). Cambridge: Cambridge University Press.

Sharma, J.C. (1983). Dental morphology and odontometry of Tibetan immigrants. American Journal of Physical Anthropology, 61, 495-505.

Shaw, J.C.M. (1931). The teeth, the bony palate and the mandible in the Bantu races of South Africa. London: J Bale and Sons.

Smith, P., Brown, T., \& Woode, W.B. (1981). Tooth size and morphology in a recent Australian Aboriginal population from Broadbeach, SE Queensland. American Journal of Physical Anthropology, 55, 432-32.

Taverne, A.A.R., Lemmens, I.G., \& Tonino, G.J.M. (1986). Lathyrogens and the role of collagen in the eruption of rat incisors. Archives of Oral Biology, 31, 127-131.

Thomsen, S. (1955). Dental morphology and occlusion in the people of Tristan da Cunha (No. 25). Norske videnskaps-akademi i Oslo.

Thompson, A.R. (2013). Odontometric determination of sex a Mound 72, Cahokia. American Journal of Physical Anthropology, 15, 408-419.

Trask, R. L. (1995). Basque and Dene-Caucasian: a critique from the Basque side. Mother tongue, 1 , 3-82.

Trask, R.L. (1997). The history of Basque. London: Routledge.

van der Heidi, H.M., Magnée, W., \& Van Loghem, J.J. (1952). Blood group distribution in Basques. American Journal of Human Genetics, 3, 356-361.

van Reenen, J.F. (1964). Dentition, jaws and palate of the Kalahari Bushman. Journal of the Dental Association of South Africa, 19, 38-44.

Yamada, T., Smith, D.C., \& Maijer, R. (1988). Tensile and shear bond strengths of orthodontic direct-bonding adhesives. Dental Materials, 4, 243-250.
Walimbe, S.R. (2009). Dental Evolution in Protohistoric Indians. In: A.R. Sankhyan, editor (pp. 215234). Asian perspectives on human evolution. New Delhi: Serials Publications.

Zorba, E., Moraitis, K., \& Manolis, S.K. (2011). Sexual dimorphism in permanent teeth of modern Greeks. Forensic Science International, 210, 74-81. 